\title{
PENGARUH KEPEMILIKAN INTERNAL, KUALITAS AUDIT DAN KEBIJAKAN HUTANG TERHADAP NILAI PERUSAHAAN PADA PERUSAHAAN MANUFAKTUR YANG TERDAFTAR DI BURSA EFEK INDONESIA
}

\author{
Zumrotun Nafi'ah dan Sopi \\ Prodi Akuntansi dan Prodi Manajemen STIE SEMARANG \\ sopi@stiesemarang.ac.id
}

\begin{abstract}
Establishment of a company has a clear goal one of which is to maximize the firm value. There are many factors affecting firm value and this study intends to empirically learning the effect of internal ownership, audit quality, and debt policy to firm value.

The population of this study is manufacturing companies listed on the Indonesian Stock Exchange for period 2017-2019, amounting to 149 companies. The sample of the study was selected as many as 11 companies with purposive sampling technique. Data collection method of this research is documentation. Data were analyzed using statistical decriptive and multiple regression analysis.

The result shows that there is no positive influence of internal ownership to firm value with $p=0.552$ ( $p>0.05)$, audit quality has significant effect to company value with $p=0.035$ $(p<0.05)$, debt policy has no significant effect on the firm value with $p=0.807(p>0.05)$.

The next study must adding other variables that also could affect the firm value such as leverage, profitability, investment, institutional ownership and others.
\end{abstract}

\section{Keywords: Internal Ownership, Audit Quality, Debt Policy and Firm Value}

\begin{abstract}
ABSTRAK
Pendirian sebuah perusahaan memiliki tujuan yang jelas salah satunya adalah untuk memaksimalkan nilai perusahaan.Terdapat banyak faktor yang mempengaruhi nilai perusahaan dan penelitian ini bermaksud menguji secara empiris pengaruh kepemilikan internal, kualitas audit, dan kebijakan hutang terhadap nilai perusahaan.

Populasi penelitian ini yaitu perusahaan manufaktur terdaftar di BEIperiode 20172019 yang berjumlah 149 perusahaan. Sampel penelitian dipilih sebanyak 11 perusahaan dengan teknik purposive sampling. Metode pengumpulan data penelitian ini adalah metode dokumentasi. Data dianalisis menggunakan uji dekriptif statistik dan analisis regresi berganda.

Hasil penelitian menunjukkan bahwa tidak terdapat pengaruh positif kepemilikan internal terhadap nilai perusahaan hal ini dibuktikan dengan signifikan kepemilikan internal sebesar 0,552 ( $>0,05)$, kualitas audit berpengaruh signifikan terhadap nilai perusahaaan, hal ini di buktikan dengan nilai signifikan kualitas audit sebesar 0,035 ( $\mathrm{p}<0,05)$, kebijakan hutang tidak berpengaruh signifikan terhadap nilai perusahaan, hal ini dibuktikan dengan nilai signifikan kebijakan hutang sebesar 0,807 ( $\mathrm{p}>0,05)$.

Penelitian mendatang perlu menambahkan variabel lain yang juga berpengaruh terhadap nilai perusahaan misalnya leverage, profitabilitas, investasi, kepemilikan institusionaldan lainnya.
\end{abstract}

\section{Kata Kunci: Kepemilikan Internal, Kualitas Audit, Kebijakan Hutang dan Nilai Perusahaan}




\section{PENDAHULUAN}

Pendirian sebuah perusahaan memiliki tujuan yang jelas diantaranya adalah memaksimalkan nilai perusahaan yang tercermin pada harga sahamnya (Sukirni, 2012). Nilai perusahaan adalah harga yang bersedia dibayar oleh calon pembeli apabila perusahaan tersebut dijual. Nilai perusahaan dapat menggambarkan keadaan perusahaan. Dengan baiknya nilai perusahaan maka perusahaan akan dipandang baik oleh para calon investor, demikian pula sebaliknya. Nilai perusahaan yang tinggi menunjukkan kinerja perusahaan yang baik (Astuti dan Setiawati, 2014).

Optimalisasi nilai perusahaan akan tercapai, ketika perusahaan dijalankan olehmanajemen yang profesional. Ketika pemegang saham tidak memiliki kemampuan profesional untuk menjalankan perusahaan, mereka akan mengangkat pihak lain untuk menjalankan perusahaannya.

Konsekuensi dari kondisi tersebut adanya pemisahan dan hubungan keaganenan antara manajer (agen) dan pemegang saham (pinsipal). Hubungan keagenan antara manajer dan pemegang saham tidakselamanya berjalan dengan baik, bahkan cenderung menimbulkan konflik yangdinamakan dengan masalah keagenan (agency problem) yang terjadi ketika manajer mempunyai tujuan yang bertentangan dengan pencapaian kemakmuran pemegang saham. Masalah keagenan tersebut akan berdampak penurunan nilai perusahaan. Agar optimalisasi nilai perusahaan dapat dicapai, masalah keagenan harus diminimumkan (Wahab dan Saiful, 2013).

Penelitian Bernhart dan Rosenstein yang dikutip oleh Wahab dan Saiful (2013) menemukan bahwa nilai perusahaan meningkat sejalan dengan peningkatan kepemilikan manajerial sampai dengan 5\%, kemudian menurun pada saat kepemilikan manajerial 5\%$25 \%$, dan kemudian meningkat kembali seiring dengan adanya peningkatan kepemilikan manajerial secara berkelanjutan. Morck et.alyang dikutip oleh Wahab dan Saiful (2013), menemukan bahwa terdapat hubungan nonlinier antara kepemilikan manajerial dengan kinerja perusahaan. Hubungan positif antara kepemilikan manajerial dengan kinerja terjadi pada level kepemilikan 0\%-5\% dan berhubungan negatif pada level kepemilikan 5\%-25\%. Ghosh (2007) menemukan bahwa 
kepemilikan manajerial berpengaruh positif terhadap nilai perusahaan. Kepemilikan manajerial berpengaruh negatif terhadap nilai perusahaan. Permanasari (2010) menemukan kepemilikan manajemen tidak memiliki pengaruh terhadap nilai perusahaan. Selain itu, Sukirni (2011) menemukan bahwa kepemilikan manajerial tidak berpengaruh signifikan terhadap nilai perusahaan. Selain kepemilikan manajerial, masalah keagenan dapat juga diminimumkan dengan pengawasan oleh auditor eksternal. Auditor eksternal bertanggung jawab untuk menyediakan informasi yang berkualitas tinggi yang akan berguna untuk pengambilan keputusan para pemakai laporan keuangan salah satunya adalah investor.

Auditor yang mempunyai kualitas audit yang baik akan membuat investor percaya terhadap informasi yang dikeluarkan oleh perusahaan yang membuat investor tidak ragu lagi untuk melakukan investasi. Kualitas audit adalah ukuran yang menunjukan adanya tingkat kompetensi dan independensi dari KAP dalam mengaudit laporan keuangan yang diperiksanya sehingga dapat memberikan suatu keyakinan atas pendapat yang telah dikeluarkan dan dapat memberikan suatu jaminan atas reliabilitas dan kualitas dari angka-angka akuntansi dalam laporan keuangan (Juliardi,2013). Wahab dan Saiful (2013) menemukan bahwa kualitas audit eksternal berpengaruh positif signifikan terhadap nilai perusahaan.

Memaksimumkan nilai perusahaan tidak hanya melalui nilai ekuitas saja yang harus diperhatikan, tetapi juga semua klaim keuangan seperti hutang, waran maupun saham preferen. Optimalisasi nilai perusahaan yang merupakan tujuan perusahaan dapat dicapai melalui pelaksanaan fungsi manajemen keuangan, dimana satu keputusan keuangan yang diambil akan mempengaruhi keputusan keuangan lainnya dan berdampak pada nilai perusahaan(Sukirni, 2012).

Kebijakan hutang menentukan seberapa besar kebutuhan dana perusahaan dibiayai oleh hutang (Weston dan Copeland dalam Sukirni, 2012). Solvabilitas (leverage) digambarkan untuk melihat sejauh mana asset perusahaan dibiayai oleh hutang dibandingkan dengan modal sendiri. Kebijakan hutang termasuk kebijakan pendanaan perusahaan yang bersumber dari eksternal. Penentuan kebijakan hutang ini berkaitan dengan struktur modal karena hutang merupakan salah satu komposisi dalam struktur modal.Menurut hasil penelitian Ikbal 
(2011) dan Sukirni (2012) menunjukkan terbukti berpengaruh terhadap nilai perusahaan. Namun hasil penelitian Astuti dan Setiawati (2014) menunjukkan bahwa kebijakan hutang tidak berpengaruh terhadap nilai perusahaan.

Riset gap yang melatar belakangi dilakukannya penelitian ini adalah adanya perbedaan hasil penelitian yaitu hasil penelitian Hermuningsih dan Wardani (2009) serta hasil penelitian Ikbal (2011) dan Sukirni (2012) dimana kepemilikan internal terbukti berpengaruh terhadap nilai perusahaan. Namun hasil penelitian Sukirni (2012) menunjukkan bahwa kepemilikan manajerial berpengaruh negatif terhadap nilai perusahaan, sedangkan dalam penelitian Astuti dan Setiawati (2014) menunjukkan bahwa kepemilikan manajerial tidak berpengaruh terhadap nilai perusahaan. Hasil penelitian Ikbal (2011) menunjukkan bahwa kualitas audit terbukti berpengaruh terhadap nilai perusahaan. Namun hasil penelitian Juliardi (2013) menunjukkan bahwa kualitas audit tidak berpengaruh terhadap nilai perusahaan. Kebijakan hutang, menurut hasil penelitian Ikbal (2011) dan Sukirni (2012) menunjukkan terbukti berpengaruh terhadap nilai perusahaan. Namun hasil penelitian Astuti dan
Setiawati (2014) menunjukkan bahwa kebijakan hutang tidak berpengaruh terhadap nilai perusahaan. Demikian halnya dengan variabel kebijakan dividen, hasil penelitian Hermuningsih dan Wardani (2018) serta hasil penelitian Ikbal (2011) menunjukkan bahwa kebijakan dividen terbukti berpengaruh terhadap nilai perusahaan. Namun hasil penelitian Astuti dan Setiawati (2014) menunjukkan bahwa kebijakan dividen tidak berpengaruh terhadap nilai perusahaan.

Tujuan penelitian ini meneliti pengaruh kepemilikan internal, kualitas audit, dan kebijakan hutang terhadap nilai perusahaan pada perusahaan manufaktur yang terdaftar di Bursa Efek Indonesia periode 2017-2019.

\section{METODE}

Sampel penelitian terdiri dari 11 perusahaan manufaktur yang terdaftar di Bursa Efek Indonesia periode 2017-2019 dan telah memenuhi kriteria yang ditetapkan (Tabel 1).

\section{Tabel 1. Tahapan Penentuan Sampel}

\begin{tabular}{lc}
\hline \multicolumn{1}{c}{ Kriteria } & Jumlah \\
\hline Perusahaan manufaktur tersebut & 149 \\
merupakan perusahaan yang go public & \\
dan terdaftar di BEI pada tahun 2017- & \\
2019 yang mencantumkan data secara & \\
lengkap berturut-turut selama periode & \\
penelitian & \\
Perusahaan tidak menerbitkan laporan & \\
keuangan audited yang lengkap pada \\
tahun 2017-2019 \\
Perusahaan tidak membagikan dividen
\end{tabular}


secara berturut - turut dari tahun 2017-

2019

Jumlah perusahaan yang di jadikan

11

sampel

Dikalikan periode pengamatan

Jumlah Data

Sumber : www.idx.co.id, 2019

Definisi operasional dari masingmasing variable ditunjukkan sebagai berikut:

1. Kepemilikan Internal

Kepemilikan internal adalah proporsi pemegang saham dari pihak manajemen yang secara aktif ikut dalam pengambilan keputusan perusahaan (direktur dan komisaris). Kepemilikan internal diukur dengan jumlah saham yang dimiliki oleh direktur dan komisaris dibagi keseluruhan jumlah saham (Wahab dan Saiful, 2013:114).

2. Kualitas audit

Kualitas audit eksternal merupakan kemampuan seorang auditor mendeteksi dan melaporkan penyelewengan yang terjadi dalam sistem akuntansi klien. Indikator kualitas audit dalam penelitian ini diukur dengan KAP Big 4 dan Non Big 4. (Wahab dan Saiful, 2013:114)

3. Kebijakan Hutang

Kebijakan hutang adalah kebijakan yang menentukan seberapa besar kebutuhan dana perusahaan dibiayai oleh hutang. Solvabilitas (leverage) digambarkan untuk melihat sejauh mana asset perusahaan dibiayai oleh hutang. Kebijakan hutang dalam penelitian ini di indikatorkan dengan leverage. Leverage adalah rasio antara jumlah total hutang dengan total modal sendiri (Wahab dan Saiful, 2013:114).

\section{Nilai Perusahaan}

Nilai perusahaan merupakan presepsi investor terhadap perusahaan, yang sering dikaitkan dengan harga saham. Nilai perusahaan disini akan diukur dengan menggunakan Tobin's $Q$ (Wahab dan Saiful, 2013:114).

Pengumpulan data penelitian ini dilakukan dengan metode dokumentasi berasal dari Indonesian Capital Market Directory (ICMD). Serta data tentang informasi laporan keuangan perusahaan manufaktur yang terdaftar di BEI darisitus www.idx.co.id.

Analisis data yang telah diperoleh dilakukan dengan uji regresi linier berganda beserta uji asumsi klasiknya menggunakan bantuan software komputer SPSS pada tingkat kemaknaan $\mathrm{p}<0,05$.

\section{HASIL}


Analisis deskriptif dari variabelvariabel penelitian ini ditunjukkan pada Tabel2.

Tabel 2. Statistik Deskriptif Variabel

Penelitian

\begin{tabular}{llllll}
\hline & $\mathrm{N}$ & Min & Max & Mean & Std. Dev \\
\hline Kepemilika & 4 &. & 25.1 & 2.42 & 0.29 \\
n internal & 4 & .00 & 8 & & \\
Kualitas & 4 & & & & \\
audit & 4 & .00 & 1.00 & .5455 & .50369 \\
Kebijakan & 4 & .15 & 2.46 & & \\
hutang & 4 & 0 & 0 & .71818 & .698478 \\
Nilai & 4 & .62 & 5.79 & 1.9637 & 1.32683 \\
perusahaan & 4 & 9 & 7 & 3 & 7 \\
\hline
\end{tabular}

Nilai terendah kepemilikan internal 0,000 dan nilai tertinggi 25,18 dengan rata-rata 2,419 dan standar deviasi sebesar 0,28. Kualitas audit terendah adalah 0,000 ; tertinggi 1,00 dengan rata-rata 0,5455 dan standar deviasi 0,503 . Nilai terendah kebijakan hutang adalah 0,150 dan tertinggi 2,460 dengan rata-rata 0,718 dan standar deviasi 0,698 .Variabel nilai perusahaan yang diindikatorkan dengan Tobin's Q memiliki nilai terendah 0,629 ; tertinggi 57,97 dengan rata-rata 1,96 dengan standar deviasi sebesar 1,326. Nilai ratarata variable penelitianyang lebih besar dari standar deviasinya menunjukkan bahwa variabel-variabel yang menjadi sampel penelitian adalah tidak berbeda.

Berdasarkan hasil uji asumsi klasik diketahui bahwa model regresi bebas dari multikolinieritas (VIF < 10)
(Tabel 3), bebas auto korelasi dengan nilai durbin Watson sebesar 2,25berada diantara du dan 4-du $((1,3263<2,225<2,280)$ (Tabel 4$)$, bebas heteroskedastisitas (Gambar 1), dan memenuhi asumsi normalitas residual ditunjukkan dengan nilai $\mathrm{p}$ uji Kolmogorov Smirnov > 0,05 (Tabel 5). Tabel 3. Hasil Uji Multikolinieritas

\begin{tabular}{lll}
\hline \multirow{2}{*}{ Variabel } & \multicolumn{2}{l}{$\begin{array}{l}\text { Collinearity } \\
\text { Statistic }\end{array}$} \\
\cline { 2 - 3 } & Tolerance & VIF \\
\hline Kepemilikan & 0,691 & 1,447 \\
internal & 0,673 & 1,486 \\
Kualitas audit & 0,532 & 1,878 \\
\hline
\end{tabular}

Sumber : Data sekunder yang diolah, 2019.

Tabel 4. Hasil Uji Autokorelasi

\begin{tabular}{ll}
\hline Koefisien & Nilai \\
\hline Durbin Watson & 2,225 \\
\hline
\end{tabular}

Sumber : Data sekunder yang diolah, 2019.

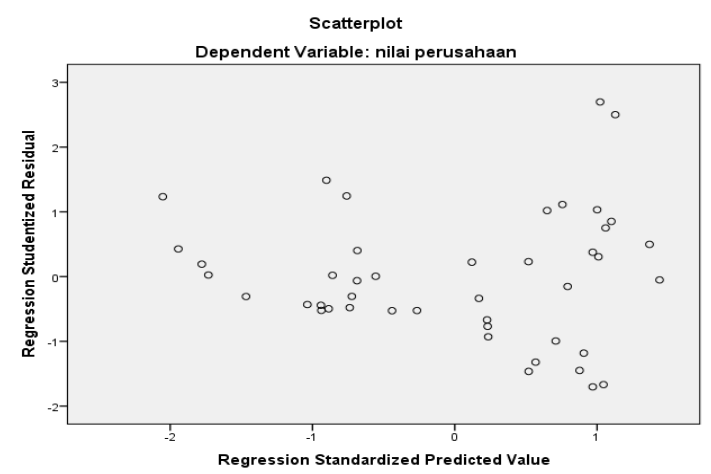

Gambar 1. Hasil Uji Heterokedastisitas Sumber : Data sekunder yang diolah, 2019 
Tabel 5. Hasil Uji Normalitas

One-Sample Kolmogorov-Smirnov Test

\begin{tabular}{lll}
\hline & & $\begin{array}{l}\text { Unstandardized } \\
\text { Residual }\end{array}$ \\
\hline $\mathrm{N}$ & & 44 \\
Normal Parameters ${ }^{\mathrm{a}, \mathrm{b}}$ & Mean & .0000000 \\
& Std. Deviation & 1.13144373 \\
Most Extreme Differences & Absolute & .097 \\
& Positive & .097 \\
& Negative & -.073 \\
Test Statistic & & .097 \\
Asymp. Sig. (2-tailed) & & $.200^{\mathrm{c}, \mathrm{d}}$ \\
\hline
\end{tabular}

a. Test distribution is Normal.

b. Calculated from data.

c. Lilliefors Significance Correction.

d. This is a lower bound of the true significance.

Hasil estimasi regresi ditunjukkan pada

Tabel 6:

Tabel 6. Nilai Koefisien Regresi

\begin{tabular}{ll}
\hline Variabel & B \\
\hline Constant & 0,988 \\
Kepemilikan internal & $-0,018$ \\
Kualitas audit & 0,958 \\
Kebijakan hutang & 0,087 \\
\hline
\end{tabular}

Sumber : Data sekunder yang diolah, 2019.

Persamaan regresi yang dihasilkan:

$\mathrm{Y}=0,988-0,018 \mathrm{X}_{1}+0,958 \mathrm{X}_{2}+0,087 \mathrm{X}_{3}$

Konstanta sebesar $\quad 0,988$

menunjukkan jika tidak ada variabel

bebas yang mempengaruhi terhadap nilai perusahaan (Y), maka nilai perusahaan (Y) yang diperoleh adalah sebesar 0,988. Koefisien regresi variabel kepemilikan internal sebesar -0,018, artinya bahwa setiap kenaikan 1 satuan kepemilikan internal, maka nilai perusahaan akan turun sebesar 0,018, demikian halnya jika kepemilikan internal turun 1 satuan, maka nilai perusahaan justru akan naik sebesar 0,018. Koefisien regresi variabel kualitas audit sebesar 0,958, artinya bahwa setiap kenaikan 1 satuan kualitas audit, maka nilai perusahaan akan naik sebesar 0,958, demikian halnya jika kualitas audit turun 1 satuan, maka nilai perusahaan juga akan turun sebesar 0,958. Koefisien regresi variabel kebijakan hutang sebesar0,087, artinya bahwa setiap kenaikan 1 satuan kebijakan hutang, maka nilai perusahaanjuga akan naik sebesar 0,087, demikian halnya jika kebijakan hutangturun 1 satuan, maka nilai perusahaan juga akan turun sebesar 0,087 .

Signifikansi atau hasil pengujian hipotesis ditunjukkan pada Tabel 7.

Tabel 7. Hasil Uji t

\begin{tabular}{lll}
\hline Variabel & Sig. & Interpretasi \\
\hline Kepemilikan internal & 0,552 & Tidak berpengaruh \\
Kualitas audit & 0,035 & Berpengaruh positif \\
Kebijakan hutang & 0,807 & Tidak berpengaruh \\
\hline Sumber : Data sekunder yang diolah, \\
2019.
\end{tabular}

Dari tiga variabel bebas yang diteliti, hanya kualitas audit yang terbukti berpengaruh signifikan terhadap nilai perusahaan $(\mathrm{p}<0,05)$.

Kelayakan model regresi ditunjukkan pada uji simultan dan diperoleh nilai $\mathrm{F}$ sebesar 3,658 dan $\mathrm{p}=$ $0,013(\mathrm{p}<0,05)$ artinya kepemilikan 
internal, kualitas audit dan kebijakan hutang secara simultan berpengaruh terhadap nilai perusahaan. Dari hasil uji koefisien determinasi diperoleh nilai $\mathrm{R}^{2}$ sebesar 0,198; artinya daya penjelas dari ketiga variabel bebas dalam penelitian ini terhadap nilai perusahaan hanya sebesar $19,8 \%$, sementara $80,2 \%$ dijelaskan oleh variabel bebas lain yang tidak disertakan dalam penelitian ini.

\section{PEMBAHASAN}

Kepemilikan internal tidak berpengaruh terhadap nilai perusahaan, hal ini terjadi karena manajemen perusahaan tidak memiliki kendali terhadap perusahaan. Manajemen lebih banyak dikendalikan oleh pemilik mayoritas. Selain itu manajemen sebagian besar tidak memiliki persentase kepemilikan dalam perusahaan, karena sebagian besar kepemilikan saham dimiliki oleh pemegang saham institusional. Hasil penelitian ini sesuai dengan hasil penelitian Astuti dan Setiawati (2014) yang berjudul analisis pengaruh profitabilitas, kebijakan deviden, kebijakan hutang, dan kepemilikan manajerial terhadap nilai perusahaan (studi empiris pada perusahaan manufaktur yang terdaftar di Bursa Efek Indonesia Tahun 2010 2012) yang menunjukkan bahwa kepemilikan internal tidak berpengaruh signifikan terhadap nilai perusahaan.

Kualitas audit terbukti berpengaruh positif dan signifikan terhadap nilai perusahaan. Auditor yang mempunyai kualitas audit yang baik akan membuat investor percaya terhadap informasi yang dikeluarkan oleh perusahaan yang membuat investor tidak ragu lagi untuk melakukan investasi. Hasil penelitian ini sesuai dengan hasil penelitian Ikbal (2011) yang berjudul pengaruh kepemilikan internal, kualitas audit, dan kebijakan hutang terhadap nilai perusahaan pada perusahaan manufaktur yang terdaftar di Bursa Efek Indonesia periode 2017-2019yang menunjukkan bahwa kualitas audit terbukti berpengaruh terhadap nilai perusahaan.

Kebijakan hutang tidak berpengaruh terhadap nilai perusahaan, hal ini disebabkan karena adanya kontrol ketat dari pihak manajemen dalam penggunaan utang. Penggunaan utang pada tingkat rendah oleh manajer dilakukan untuk mengantisipasi kemungkinan terjadinya financial distress dan risiko kebangkrutan. Demand hypothesis menjelaskan bahwa perusahaan yang dikuasai oleh insider menggunakan utang dalam jumlah besar untuk mendanai perusahaan. Semakin 
terkonsentrasi kepemilikan saham maka pengawasan yang dilakukan pemilik terhadap manajemen semakin efektif. Manajemen akan semakin hati-hati dalam memperoleh pinjaman, sebab jumlah utang yang semakin meningkat akan menimbulkan financial distress. Terjadinya financial distressakan mengakibatkan nilai perusahaan akan mengalami penurunan sehingga mengurangi kemakmuran pemilik sehingga mengurangi nilai perusahaan tersebut (Sri dan Pancawati, 2011).

Hasil penelitian ini sesuai dengan hasil penelitian Astuti dan Setiawati (2014) yang berjudul analisis pengaruh profitabilitas, kebijakan deviden, kebijakan hutang, dan kepemilikan manajerial terhadap nilai perusahaan (studi empiris pada perusahaan manufaktur yang terdaftar di Bursa Efek Indonesia Tahun 2010 - 2012) yang menunjukkan bahwa kebijakan hutang tidak berpengaruh terhadap nilai perusahaan.

\section{KESIMPULAN}

Kesimpulan penelitian ini adalah dari tiga variable bebas yang diteliti, hanya kualitas audit yang terbukti berpengaruh terhadap nilai perusahaan manufaktur yang terdaftar di Bursa Efek Indonesia periode 2017-2019, sedangkan kepemilikan internal dan kebijakan hutang tidak berpengaruh. Penelitian mendatang perlu ditambahkan faktorfaktor lain yang juga dapat mempengaruhi nilai perusahaan. Indikator lain dari nilai perusahaan dengan rumus yang lebih kompleks daripada nilai Tobin's Q juga perlu diterapkan.

\section{DAFTAR PUSTAKA}

Astuti dan Setiawati.2014.“Analisis Pengaruh Profitabilitas, Kebijakan Deviden, Kebijakan Hutang, dan Kepemilikan Manajerial terhadap Nilai Perusahaan (Studi Empiris pada Perusahaan Manufaktur yang Terdaftar di Bursa Efek Indonesia Tahun 2010 - 2012)". Seminar Nasionaldan Call For Paper. StudiAkuntansi-FEB UMS.

Ghosh. 2007. "External Auditing, Manajerial Monitoring and Firm Valuation : An empirical analysis for india". MPRA paper No. 17142.

Hermuningsih dan Wardani. 2009. "Faktor-Faktor yang Mempengaruhi Nilai Perusahaan pada Perusahaan yang Terdaftar di Bursa Efek Malaysia dan Bursa Efek Indonesia". Jurnal Siasat Bisnis. Vol. 13No. 2,Agustus.

Ikbal,Muhammad, dkk. 2011. "Pengaruh Profitabilitas dan Kepemilikan Insider terhadap Nilai Perusahaan Dengan Kebijakan Utang dan Kebijakan Dividen Sebagai Variabel Intervening (Studi pada Perusahaan Manufaktur di Bursa Efek Indonesia)". Simposium Nasional Akuntansi XIV.Aceh. 
Juliardi, Dodik. 2013. "Pengaruh Leverage, Konsentrasi Kepemilikan dan Kualitas Audit terhadap Nilai Perusahaan Serta Laba Persisten pada Perusahaan-Perusahaan Publik Manufaktur yang Listed di Bursa Efek Indonesia (Studi Perbandingan antara Perusahaan-perusahaan Manufaktur yang Diaudit KAP 4 Besar dan KAP Non 4 Besar)". Jurnal Akuntansi Aktual, Vol. 2, Nomor 2, Juni.

Sri dan Pancawati, 2011. "Struktur Kepemilikan, Kebijakan Deviden,
Kebijakan Utang, dan Nilai Perusahaan". Dinamik Keuangan dan Perbankan. ISSN : 1979-4878. Vol. 3 No. 1, Mei, 2011 : 68-87.

Sukirni, Dwi. 2012. "Kepemilikan Manajerial, Kepemilikan Institusional, Kebijakan Deviden dan Kebijakan

Wahab dan Saiful, 2013. "Kepemilikan Internal, Kualitas Auditor, dan Nilai Perusahaan". Jurnal Fairness. Volume 3 Nomor 1. Maret. 